\title{
PAINTING AND POETRY: EZRA POUND'S “SEVEN LAKES CANTO” AND EIGHT VIEWS OF XIAO XIANG
}

\section{PINTURA E POESIA: "SEVEN LAKES CANTO" DE EZRA POUND E OITO VISTAS DE XIAO XIANG}

Hongxin Jiang ${ }^{1}$

\begin{abstract}
Resumo: Na história das trocas culturais entre a China e o Ocidente, é um feito amplamente louvado que as pinturas chinesas Oito Vistas de Xiao Xiang tenham exercido grande influência na obra poética de Ezra Pound "Seven Lakes Canto" ou "Canto 49". Ao explorar os detalhes das pinturas e traçar a influência das pinturas na criação do poema, este artigo revela que o uso etimológico e composicional dos ideogramas chineses teve um enorme impacto no pensamento de Pound sobre poesia e assuntos culturais, e na escrita dos Cantos. Pound, ao adotar as imagens da China em Oito Vistas de Xiao Xiang, encontra outro paraíso, de modo que os elementos culturais chineses lhe possibilitaram criar uma nova entidade em seus próprios termos: o poema poundiano. A discussão de "Seven Lakes Canto", de Pound, a partir de suas teorias poéticas e tradutórias, comprova que o poema pode de fato ser percebido como um modo único de interpretar e apresentar a China.
\end{abstract}

Palavras-chave: Ezra Pound; "Seven Lakes Canto"; Oito Vistas de Xiao Xiang

Abstract: In the history of cultural exchange between China and the West, it's a deed praised far and wide that the Chinese paintings Eight Views of Xiao Xiang had exerted great influence on Ezra Pound's poetic work "Seven Lakes Canto" or "Canto 49." By exploring the details of the paintings and tracing the influence of the paintings on the creation of the poem, this paper reveals that the etymological and compositional use of Chinese ideograms had an enormous impact on Pound's thinking about poetry and cultural matters, and on the writing of The Cantos. Pound, by adopting the images of China in Eight Views of Xiao Xiang, finds another paradise, so the Chinese cultural elements enabled him to create a new entity in its own right: the Poundian poem. Discussion of Pound's "Seven Lakes Canto" from his poetic and translation theories certifies that the poem can actually be perceived as a unique way of interpreting and displaying China.

Keywords: Ezra Pound; "Seven Lakes Canto"; Eight Views of Xiao Xiang

\section{Introduction}

The Cantos is the logbook of Ezra Pound (1885-1972) who made a poetic voyage through ancient cultures and the history of the world, through Greek mythology, ancient China and Egypt, Byzantium, Renaissance Italy, and many other periods and subjects, which are poetically reorganized in the nooks and crannies of his own memory and experience. There are numerous passages that are composed based on his knowledge of diverse civilizations and nations. Pound's verse took on new qualities when he began adopting some concrete details and precise visual images from Chinese literature to capture poetic moments of life, thus reanimating the highest classical standards.

"Canto 49" is also referred to as "Seven Lakes Canto." It is the most important and beautiful part of The Cantos. According to Pound's daughter Mary de Rachewiltz, this section

\footnotetext{
${ }^{1}$ Hunan Normal University, Changsha, China 410081; https://orcid.org/0000-0002-8659-2654; jhxin@hunnu.edu.cn
} 
was also Pound's favorite in his entire cantos. This canto bears a close relationship with the paintings of "Eight Views of Xiao Xiang" and the people of Hunan province, which have a long history of influence and dissemination. This paper will investigate the documentary evidence and poetic sources, and some etymological compositional uses of Chinese ideograms in "Canto 49" to shed fresh new light on the relationship between The Cantos and Chinese poetry and how the symbiosis resulted in a new creation in its own right: the Poundian poem.

\section{The Paintings of Eight Views of Xiao Xiang}

Song Di (ca.1015-ca.1080), a Northern Song painter-scholar, was exiled to Hunan as were many unfavored officers in ancient China. One day he traveled by boat on the Xiang River. He was greatly attracted to the beautiful scenes and excited by the eagerness of drawing a painting to express feelings. Then he returned home and drew the paintings of the eight views. There were some notes and records about Song Di and his painting in the historic documents. His contemporary Shen Kuo, a scholar and scientist, in his masterpiece Mengxi Jottings presented a chapter about painting which includes a profile of Song Di and his paintings of the eight views (Ba Jing). He said that Mr. Song Di, an exiled officer, was good at painting, especially those of landscapes. The most satisfying examples of his paintings include "Wild Geese Alighting on Sandbar," "Sailboats Returning from Distant Shore," "Mountain and Town in Clear Mist," "River and Sky in Evening Snow," "Autumn Moon over Lake Dongting," "Night Rain in Xiao Xiang," "Evening Bell from Mist-shrouded Temple" and "Fishing Village in Twilight Glow." They are collectively named "Eight Views" (Hu 549).

Shen Kuo added that the stories about the paintings had been much richer in the past. Su Shi, the great poet and a friend of Song Di, recalled that he had been once watching Song Di "working with facility and forgetting his brush" in "Three Poems on Song Di Painting Evening Views on the Xiao-Xiang" (805). Time has fulfilled the prediction of Shen Kuo. Since then, the poems of Su Shi and the story of Song Di's paintings have stimulated more poets and artists to work on the eight views. Many paintings or individual scenes were produced and claimed using this or a similar name to Song Di's eight views (Ba Jing). Two representative paintings of this type exist in ancient China. One, titled "The Grand View of Xiao Xiang," was drawn by Mi Youren in the Song dynasty and is now preserved in the Palace Museum in Beijing. The other painting, drawn by Wang Su in the Qing dynasty, is titled "Autumn Moon over Lake Dongting." There is a pattern of extraordinary occurrences in the history of cultural communication between China and Japan. Many ancient paintings named Eight Views of Xiao Xiang, such as the works of Chuan Muxi, are now exhibited in Japanese museums. In the later period, though the paintings failed to be handed down from past generations, the stories about the paintings and the relevant poems were still spread in China. They were even passed on to Japan since the Song dynasty. Ran Yi, a Chinese scholar, in Japan researched information about Eight Views of Xiao Xiang, and discovered at least 20 pieces from the Song to the Qing dynasty now in the collections of Japanese museums. Japanese enthusiasm for Eight Views of Xiao Xiang grew as centuries passed by and the Japanese built their own Eight Views by imitating the original versions from China with some minor changes such as compositional details in the Japanese style, for example the "Eight Views of Omi."

\section{The Voyage of a Japanese Screen Book Comprising Eight Views of Xiao Xiang to Ezra Pound}

The artistic influence of these paintings soon spread to the field of modern American poetry in America. Images from the paintings were noticed and used poetically by Pound. One of the results is his "Canto 49," which reads as follows:

For the seven lakes, and by no man these verses 
Rain, empty river, a voyage,

Fire from frozen cloud, heavy rain in the twilight

Under the cabin roof was one lantern

The reeds are heavy, bent,

and the bamboos speak as if weeping

Autumn moon, hills rise about lakes

against sunset

Evening is like a curtain of cloud,

a blurr above ripples, and through it

sharp long spikes of the cinnamon,

a cold tune amid reeds

Behind hill the monk's bell

borne on the wind.

Sail passed here in April, may return in October

Boat fades in silver, slowly;

Sun blaze alone on the river

Where wine flag catches the sunset

Sparse chimneys smoke in the cross light

Comes then snow scur on the river

And a world is covered with jade

Small boat floats like a lanthorn,

The flowing water clots as with cold. And at San Yin

they are a people of leisure

Wild geese swoop to the sand-bar,

Clouds gather about the hole of the window

Broad water, geese line out with the autumn

Rooks clatter over the fishermen's lanthorns,

A light moves on the north sky line,

where the young boys prod stones for shrimp

In seventeen hundred came Tsing to these hill lakes

A light moves on the south sky line

State by creating riches shd thereby get into debt?

This is infamy, this is Geryon.

This canal goes still to Tenshi

though the old king built it for pleasure

KEI MEN RAN KEI

KIU MAN MAN KEI

JITSU GETSU KO KWA

TAN FUKU TAN KAI

Sun up, work

sundown, to rest

dig well and drink of the water

dig field, eat of the grain 
Imperial power is? and to us what is it?

The fourth, the dimension of stillness

And the power over wild beasts (The Cantos 245)

This poem is a collage consisting of the following sources: 1) The first 32 lines are based on sixteen poems (eight Japanese and eight Chinese) with accompanying paintings, which describe eight famous views (Eight Views of Xiao Xiang) in Hunan, Central China; 2) Lines 33-36 record Pound's own voice; 3) Lines 37-40 are inspired by a famous Chinese song "The Song to the Auspicious Cloud" which is credited to the Emperor Shun (2255 B.C.-2205 B.C.). A Japanese version with English notes was amongst the Fenollosa papers in Pound's possession, and is also the source of the present lines in Romanized Japanese (Cookson 53); 4) Lines 4145 , a translation of an ancient Chinese folksong "Ji Rang Ge" (Clod-beating Song), dated from the time of Emperor Yao, Shun's predecessor, and were taken from a second version created by Fenollosa (Cookson 53); 5) The ending lines are in Pound's own voice.

According to Christine Froula in A Guide to Ezra Pound's Selected Poems: "Pound did a first translation of the eight Chinese poems in the screen book in the spring of 1928, with the help of a Chinese visitor, Pao-sun Tseng, founder and president of the Yifang Women's College. Only many years later did he decide to use the translations in The Cantos. He adapted them freely for that purpose, rearranging them and interpolating images from one into another." (182) This information is based on a letter from Pound to his parents. But a key question remains: what is the original source from which the collaboratively translated version by Zeng Baosun (Pao-sun Tseng) and Pound is derived? Pound received the screen book from his parents in 1928, which consists of eight poems in Chinese and another eight in Japanese, which together represent eight classic views of the Xiao and Xiang Rivers in Central South China. Eight Views of Xiao Xiang: Japanization of Chinese Poems and Pictures addresses the travel of Eight Views of Xiao Xiang to Japan. In this book, the author quotes the Chinese monk-poet Yu Jian's eight poems in Chinese, accompanied accordingly by eight poems in Japanese and eight painted scenes (Takaji 198-201). The contents of these poems faithfully correspond to Zeng and Pound's collaborated translation. In discussing this subject, Hugh Kenner did not identify this source in his relevant essay "More on the 'Seven Lakes Canto." Wai-lim Yip in his book Pound and the Eight Views of Xiao Xiang discovered this clue. According to his textual research, the paintings of Eight Views of Xiao Xiang in the screen book were created by a Japanese calligrapher Genryu or Sasaki Genryu. Each painting was inscribed with both Chinese and Japanese poems. Those anonymous Chinese poems were quite similar to the monk-poet $\mathrm{Yu}$ Jian's "Poems of Eight Views," which was introduced into Japan in the $11^{\text {th }}$ century. Wai-lim Yip commented Genryu's paintings initiated vast scales of importation and imitations of the "Poems of Eight Views" created by Yu Jian and Mu Qi, including the brush-techniques, the spatial deployment and the motif of poetry (199). By comparing the Chinese poems in the screen book, Zeng's rough drafts, Pound's transfiguration of these poems in "Seven Lakes Canto," Wai-lim Yip concluded that Pound finished the writing of "Seven Lakes Canto" based upon the inscribed poems on Genryu's paintings. His analyses thus confirmed my findings.

A Student's Guide to the Selected Poems of Ezra Pound compiled by Peter Brooker states that Angela Jung Palandri has been able to add the information that Pound was assisted in making these translations by a Miss Zeng Baosun who visited him in Rapallo sometime between 1 March and 17 May 1928. In comparison with other scholarship, this reference provides the most detailed version of the Chinese Lady Zeng Baosun. But there is still more information worthy of mention and study. Her great grandfather Zeng Guofan was a very important figure as a commander of Hunan armies, prime minister of the late Qing dynasty, and a great scholar. 
He had suppressed the uprising of Taiping Tianguo, advocated an open-door policy, faithfully followed the doctrine of Confucius, and set up a new school of Xiang. It is because of his excellence in many respects that the two competitors Mao Zedong, Chairman of the Chinese Communist Party, and Chiang Kai-shek, head of the Kuomintang, admired him so much. Zeng's grandfather, Zeng Jihong, was a mathematician. Her father Zeng Guangjun was also a high-rank administrator in the Qing dynasty. And he was very wise in cultivating his children. In her autobiography, Zeng Baosun noted there were three things she owed to her father: he didn't have his daughter's feet bound as other girl did at quite early ages; he didn't betroth his daughter at an early age, instead leaving marriage as her decision; and he supported his daughter to go abroad, even to be baptized in a Christian church. In the spring of 1912, she went to Britain to study under the patronage of Louise Barnes, once headmaster of Mary Vaughan High School in Hangzhou. In the summer of 1916, Zeng received her Bachelor's degree in Science, the first Chinese woman to receive such a degree in Chinese history. Later she returned to her native Hunan Province, where she set up Yifang Women's College in Changsha.

She discusses her meeting with Pound in her autobiography. In spring 1928, she went to Jerusalem via Turkey and Italy to attend an international Christian conference. In Italy, her friend Shu Mang took her to visit Pound and his wife in Rapallo. Zeng wrote:

Ezra Pound is an American poet, but for most of his life he lived in Italy. His poems won many prizes, and T.S. Eliot hailed him as the greatest poet of the $20^{\text {th }}$ century. Pound loved Chinese poetry so much, especially Book of Poetry, which he put into English. When I was in Italy, my friend Shu Mang arranged for me to meet him and his wife. We talked a lot about Chinese culture, poetry and traditional moral issues, and it was a pleasant conversation. (215-216)

Details of this meeting become clearer and more significant when combined with studies of Pound's letters to his parents and Zeng's autobiography. In 1928 Pound wrote a letter to his parents quoting Zeng Baosun's oral paraphrase:

Chinese book reads as follows, rough trans:

Rain, empty river,

Place for soul to travel (for room to travel)

Frozen cloud, fire, rain damp twilight.

One lantern inside boat cover (i.e. sort of shelter, not awning on small boat)

Throws reflection on bamboos branch, causes tears

AUTUMN MOON ON TON-Ting Lake

West side hills

screen off evening clouds

Ten thousand ripples send mist over cinnamon flowers.

Fisherman's flute disregards nostalgia

Blows cold music over cotton bullrush.

Monastery evening bell

Cloud shuts off the hill, hiding the temple

Bell audible only when wind moves towards one,

One can not tell whether the

Summit, is near or far, 
Sure only that one is hollow of mountains.

Autumn tide,

AUTUMN TIDE, RETURN SAILS

Touching <green> sky at horizon, mists in suggestion of autumn

Sheet of silver reflecting all that one sees

Boats gradually fade, or are lost in turn of the hills,

Only evening sun, and its glory on the water remain.

Spring in hill valley

Small wine flag waves in the evening sun

Few clustered houses sending up smoke

A few country people enjoying their evening drink

In time of peace, every day is like spring.

SNOW ON RIVER

Cloud light, world covered with < milky $>$ jade

Small boat floats like a leaf

Tranquil water congeals it to stillness

The people of San Yin are unhurried

Wild geese stepping on sand

Just outside windows, light against clouds

A few lines of autumn geese on the marsh

at their

Bullrushes have burst into snow-tips

The birds stop to preen their feathers.

EVENING IN SMALL FISHING VILLAGE.

Fisherman's light blinks

Dawn begins, with light to the south and north

Noise of children hawking their fish and crawfish

Fisherman calls his boy, and takes up big wine bottle,

They drink, they lie on the sand

And point to marsh-grass, talking. ("EP to Homer Pound" 15-17)

It is most meaningful to determine the extent to which Pound relied on Zeng's "paraphrases" to produce his poetry and how he took his poetic sources, - the pictures in the "screen book" - into account. Some of Qian Zhaoming's interpretations are highly persuasive, such as the interpretation of the phrase "Night Rain" in his paper "Seven Lakes Canto: the Cooperation Wonder of Ezra Pound and Zeng Baosun." He points out that by comparing the oral paraphrase and Pound's poem we find they share the same number of lines. The images and words "rain," "empty river," "frozen cloud," "fire," "twilight," "one lantern," and "bamboo" in the oral paraphrase are appropriated in Pound's poem. Although some words are slightly different, they express similar images and connotations. For example, "boat cover" in the oral paraphrase is replaced by "cabin roof" in Pound's poem; "to travel" is replaced by "a voyage." The line "Throws reflection on bamboo branch, causes tears" is adapted into "the bamboos speak as if weeping." With Zeng's oral paraphrase, we might infer that Pound could have been looking at the painted scene Night Rain, in which he could decipher rain in an empty river, three bold strokes in the middle as a small boat amid bent reeds, and blankness across distant hills as 
a chilled cloud. "Place for soul to travel" should signify a "voyage" even though no characters in the Chinese poem could provide confirmation. Obviously, the artistic conception expressed in the first six lines of "Seven Lakes Canto" is surprisingly consistent with that in the blending of poetry and painting. However, "Seven Lakes Canto" is not merely a translation but a recreation after the transformation of two forms of art. A striking example of this process is that neither in the original poem nor in the oral paraphrase exists "the reeds are heavy, bent." Pound could only forge this line by referring to the image of the "reed" in the original painting and in the later part of Zeng's oral paraphrase.

\section{Interpretation of "Seven Lakes Canto" from Ezra Pound's Poetic and Translation Theories}

Viewing all of the eight views together, we can find a continuous flow in meaning and color instead of fragmented pictures. In the opening line, the poet uses a key word "voyage," which could be interpreted as referring to a woeful person-perhaps a scholar, poet or artistwho first appears woeful as indicated by the phrase "and the bamboo speaks as if weeping" (last line, first stanza). As the voyage proceeds, the poem's mood becomes more harmonious and pleasant (for example, lines like "wine flag catches the sunset," "a world is covered with jade," "they are a people of leisure," and "the young boys prod stones for shrimp"). Accordingly, the shift in color gradation signals a shift in mood. While in Night Rain and Autumn Moon the dominant atmosphere is gloom, in Snowy Evening and Wild Geese it is serenity and leisure, and in Mountain Town and Fishing Village, calm and gaiety. Pound was often able to penetrate through the literal surface to grasp the integrity of a poem as a whole and then to transmit his insight and understanding into the artifice of a new medium, thus enabling the structure of feeling to generate itself, organically, according to its own inner compulsion and momentum. What emerges at the end of this process becomes a new creation in its own right: "a Poundian poem" (Nadel 210). This etymological, compositional use of Chinese ideograms, from which Pound derived his "ideogrammic" method, had an enormous impact on his thinking about poetry and cultural matters, and on the writing of The Cantos.

For Pound, the poem is a product imbued with both the art of poetry and painting. Artistic elements of painting can sometimes go into poetry, and poetry can borrow the visual effects of painting. The poet Su Shi once called great poems "pictures without forms" and great paintings "unspoken poems." Commenting on Wang Wei, the Tang Dynasty poet-painter, he says that in Wang Wei's poems one can find paintings, and in Wang Wei's painting, one can find poetry. Qian Zhongshu says that poetry and painting can be called twin-art (Qian 4). Pound's poems exemplify these critical perspectives. This type of poem is abundant in Pound's works. He frequently breaks normal syntax into striking images which are followed by others to enhance the visual effects of painting, and to juxtapose these images in order to inspire more associations and imagination on the part of the reader. This poetic method is used often in his early writings such as "In a Station of the Metro" (1913) and "The Coming of War: Actaeon:"

An image of Lethe, and the fields

Full of faint light but golden,

Gray cliffs, and beneath them

A sea

Harsher than granite, unstill, never ceasing. ("The Coming of War" 24)

These features permeate his masterpiece The Cantos:

Pearl, great sphere, and hollow,

Mist over lake, full of sunlight (The Cantos 141) 
Tching prayed on the mountain and

新 hsin wrote MAKE IT NEW

on his bath tub 日 jih

Day by day make it new

cut underbrush， 日 jih

pile the logs

keep it growing

新 hsin (The Cantos 265)

In these lines Pound applies Chinese words and quotations from Daxue (The Great Learning, in his translation) directly into his Cantos. He adds his own interpretations as well, and also incorporates these interpretations into poems because he believes Chinese characters are beautiful, and thus can serve as an effective medium for writing poetry.

Secondly, in the light of translation theory and practice, Pound also promotes such profound ideas as those in a letter to his friend William Carlos Williams in 1908 (Paige 263): 1) to paint the thing as I see it; 2) beauty; 3) freedom from didactism.

In the Spirit of Romance, Pound explains his ideas on the art of translation. He considers poetry as "a sort of inspired mathematics, which gives us equations, not for abstract figures, triangles, spheres, and the like, but equations for human emotions." Pound sets out to define poetic translation not so much as the literal and verbal equivalent of the text translated but rather as the equation of the emotion behind it (Singh 16). In fact, for Pound, there is "no literal translation of a thing where the beauty is melted into the original phrase" (Kenner 17); further, every great age has some good, even great translation, and "yet some of the best books in English are translations" (Kenner 17). According to Pound, fidelity to the original is mainly concerned with the meaning and atmosphere. In his perspective, there are three "kinds of poetry:" 1) Melopoeia, wherein the words are charged, over and above their plain meaning, with some musical property, which directs the bearing or trend of that meaning. It is practically impossible to transfer or translate it from one language to another, save perhaps by divine accident and for half a line at time; 2) Phanopoeia, which is casting of image upon the visual imagination. It can, on the other hand, be translated almost, or wholly intact; 3) Logopoeia, "the dance of the intellect among words." It does not translate; though the attitude of mind it expresses may pass through a paraphrase or one might say, you can not translate it "locally," but having determined the original author's state of mind, you may or may not be able to find a derivative or an equivalent.

The comparison between the three translated versions of the poetry by Emperor Wu Di serves as illustrations. When Pound read Herbert A. Giles's A History of Chinese Literature, he might have been impressed by Giles's words about this Chinese Emperor. Giles mentioned that Wu Di was an enthusiastic patron of art and literature, and he used music as an element to govern the country. Additionally, this emperor was a skillful poet. When one of his concubines, Lady Li, had died, the Emperor wrote this poem out of sorrow, which was translated by Giles:

The sound of rustling silk is stilled,

With dust the marble courtyard filled;

No footfalls echo on the floor,

Fallen leaves in heaps block up the door...

For she, my pride, my lovely one, is lost,

And I am left, in hopeless anguish tossed. (Giles 100)

Pound's adaptation reads in the following:

The rustling of the silk is discontinued,

Dust drifts over the court-yard, 
There is no sound of footfall, and the leaves

Scurry into heaps and lie still,

And she the rejoicer of the heart is beneath them:

A wet leaf that clings to the threshold. (Pound "Liu Ch'e" 286)

Giles's translation was literal; he not only tried to reveal the original meaning, but also to explore the AABBCC rhyme-scheme in order to emphasize the Chinese musical rhyme. Referring to Giles's translation, Pound rewrote this poem using his method of creative translation. Having dispensed with Giles's rhythm and rhyme, he consciously separated the last line from the preceding lines in order to emphasize the image "a wet leaf that clings to the threshold" in place of "and I am left, in hopeless anguish tossed." This revision echoes his imagist credo. When Pound's Cathay became very popular in the early years of the twentieth century in the English-speaking world, Arthur Waley was unsatisfied with Pound's translation. This great translator of Chinese poetry did not provide extensive criticism of Pound, but he himself retranslated the poems that Pound had translated in Cathay. But in Pound's perspective, more than mere preparation to stimulate his own creative faculties, translation served as an "adjunct to the Muses' diadem" and assumed an importance seldom found in other modern poets. Pound's translations stimulated and strengthened his poetic innovations, which in turn guided and promoted his translations. Pound's poetics is essentially a poetics of translation and he has largely redefined the nature and ideal of poetic translation for the twentieth century (Nadel 204).

Furthermore, the poem mentioned above is not just limited to the eight views. Pound explores further in the light of political and cultural criticism. Pound mentioned "Geryon" in the line "State by creating riches shd thereby get into debt? / This is infamy, this is Geryon" (The Cantos 245). "Geryon" is the three-headed or three-bodied monster slain by Hercules. In Dante's Inferno 37, Geryon, the guardian of the eighth circle of hell and a symbol of fraud, is represented as having a man's head, a beast's trunk, and a serpent's tail. In "Canto 15," Pound mentioned "the beast with a hundred legs, USURA." In "Canto 51", Geryon is presented as "twin with usura." In The Cantos, usura is his repeated target. In "Canto 45," there are long critical passages: "With Usura / With usura hath no man a house of good stone" (The Cantos 229). In "Canto 51," he continues this criticism: "In seventeen hundred came Tsing to these hill lakes / A light moves on the south sky line" (The Cantos 245).

According to references about Emperor Kangxi's journey to "hill lakes," Emperor Kangxi made six "southern tours" (from 1684-1707) and saw "hill lakes" not in the Xiao Xiang region but in Suzhou and Hangzhou in the Yangtze Delta. Here this line may prefigure the Chinese History Cantos. "The old king" may refer to Emperor Sui Yangdi (605-618). Pound owed his knowledge in these lines to Fenollosa, who investigated Mori's comment in his notebook: "he made a canal from Benrio (Kaifong) to Yosingo, and they say that he did this for his own pleasure." Pound simply substituted "Tenshi" for "Kaifong" and proceeded: "This canal goes still to Tenshi / though the old king built it for pleasure." Then he quoted two ancient songs, "Qing Yun Ge" (The Song to the Auspicious Cloud) supposedly by the legendary Emperor Shun and "Ji Rang Ge" (Clod-beating Song) supposedly by the legendary Emperor Yao, which are then incorporated into the canto to recall a golden age. Both songs are derived from a notebook in which Fenollosa recorded Mori's lectures on Chinese poetry, and in fact, the first song "Qing Yun Ge" is rendered in the sound of Japanese, in Kenner's words, which is a way to remind us that "the Chinese had come to Pound by way of Japan." In his translation, the phrase "stillness" recalls the Confucian doctrine of The Unwobbling Pivot: "what exists plumb in the middle is the just process of the universe and that which never wavers or wobbles is the calm principle operant in its mode of action." The phrase "fourth...dimension" may be a reply to Einstein's 
notion of the "fourth dimension" in his theory of relativity. Pound found it "confusing in Einstein" and of "no philosophic bearing." In "Canto 17," he describes Venice as a stone place and a paradise of the earth. By adopting images in Eight Views of Xiao Xiang of China, Pound finds another paradise.

What matters for Pound seems not so much the translation from one language or culture into another as the metamorphic passage or inter-traffic between them which can be described as his method of "ideogrammic" translation of what he thinks to be significant cultural elements and values. It tries to suggest a "compendious" (Pound $A B C$ 101) which combines facts and ideas belonging to different cultural traditions to constitute a universal paideuma, a term used by Leo Frobenius and described by Pound as "the tangle or complex of the inrooted ideas of any period." The Cantos thus significantly construct an internally allusive and self-cohesive frame of imaginative meanings and equivalences. "But the new contexts of ideogrammic juxtapositions, invoking heterogeneous traditions, also necessarily point to different directions and cultural roots" (Nadel 218). Throughout the process of Pound's poetic creation and translation, he sought the objective presentation of material in other cultures which he thought could stand independently, without the necessity of resorting to symbolist, expressionistic, or romantic ways. He indicated the properties of this method:

By contrast to the method of abstraction, or of defining things in more and still more general terms, Fenollosa emphasizes the method of science, "which is the method of poetry', as distinct from that of 'philosophic discussion', and is the way the Chinese go about it in their ideograph or abbreviated picture writing. (Pound $A B C 20$ )

To this end, the Chinese cultural constituents, to be integral for The Cantos, provided Pound with valid examples of the newly-formed objective method. The Chinese ideogram, he expounded, "is still the picture of a thing; of a thing in a given position or relation, or of a combination of things. It means the thing or the action or situation, or quality germane to the several things that it pictures" (Pound $A B C 21$ ).

\section{Conclusion}

As an internationally renowned poet, Ezra Pound has always been studied and interpreted. In particular, his monumental work The Cantos, though complex and obscure in content, has attracted scholars from generations to generations to immerse themselves in the poem, attempting to explore all kinds of mysteries hidden in it. The close relationship between Pound and China in "Seven Lakes Canto" or "Canto 49," an important part of The Cantos, is one of the mysteries. Through the study of this paper, we can find that the source of "Seven Lakes Canto" can be traced back to the paintings Eight Views of Xiao Xiang created by Song Di, a Northern Song painter-scholar. With the passage of time, the paintings failed to be handed down from past generations. However, the stories about the paintings and the relevant poems were still spread in China. They even crossed the national boundaries and reached Japan. During his stay in Italy, Pound received from his parents a screen book of Eight Views of Xiao Xiang, which included eight Chinese and Japanese poems. Chinese lady Zeng Baosun helped him to interpret the eight Chinese poems, based upon which he began to create "Seven Lakes Canto." From a macro point of view, the etymological and compositional use of Chinese ideograms had an enormous impact on Pound's thinking about poetry and cultural matters, and on the writing of The Cantos. Pound, by adopting the images of China in Eight Views of Xiao Xiang, finds another paradise, so the Chinese cultural elements enabled him to create a new entity in its own right: the Poundian poem. Discussion of Pound's "Seven Lakes Canto" from his poetic and translation theories certifies that the poem can actually be perceived as a unique way of interpreting and displaying China. 


\section{WORKS CITED:}

BROOKER, Peter. A Student's Guide to the Selected Poems of Ezra Pound. Faber and Faber, 1979.

COOKSON, William. A Guide to the Cantos of Ezra Pound. Croom Helm, 1985.

FENOLLOSA, Ernest. The Chinese Written Character as a Medium for Poetry. City Lights Books, 1936.

FROULA, Christine. A Guide to Ezra Pound's Selected Poems. New Directions, 1983.

GILES, Herbert A. A History of Chinese Literature. Grove Press, Inc., 1923.

HU, Daojing. Emendation of Mengxi Jottings. Shanghai Classics Publishing House, 1987.

KENNER, Hugh. The Translations of Ezra Pound. New Directions, 1963.

KENNER, Hugh and HESSE, Eva. Paideuma: A Journal Devoted to Ezra Pound

Scholarship. University of Maine, 1972.

NADEL, Ira B. The Cambridge Companion to Ezra Pound. Cambridge University Press, 1999.

PAIGE, D. D. The Letters of Ezra Pound, 1907-1941. Harcourt Brace and Company, 1950. POUND, Ezra. ABC of Reading. Routledge, 1934.

—. "EP to Homer Pound." Ezra Pound's Chinese Friends, edited by Qian Zhaoming.

Oxford University Press, 2008.

—. "Liu Ch'e." Ezra Pound: Poem and Translation, edited by Richard Sieburth. The

Library of America, 2002.

- The Cantos of Ezra Pound. Faber \& Faber, 1975.

—. "The Coming of War." Ezra Pound's Poetry and Prose. Garland Publishing, Inc., 1991.

QIAN, Zhaoming and Ou Rong. "Seven Lakes Canto: The Cooperation Wonder of Ezra

Pound and Zeng Baosun." Comparative Literature in China, no. 1, 2012, pp. 90-101.

QIAN, Zhongshu. Patchwork: Seven Essays on Art and Literature. Shanghai Classics

Publishing House, 1985.

SINGH, G. Ezra Pound as Critic. St. Martin's Press, 1994.

SU, Dongpo. Complete Works of Su Dongpo. Zhuhai Publishing House, 1996.

TAKAJI, Horikawa. Eight Views of Xiao Xiang: Japanization of Chinese Poems and Pictures. Linsen Bookstore, 2002.

WAI-LIM, Yip. Pound and the Eight Views of Xiao Xiang. National Taiwan University Press, 2008.

ZENG, Baosun. Memoirs of Zeng Baosun. Taiwan Longwen Incorporated Publishing Company, 1989.

Hongxin Jiang is Full Professor of English language and literature and Executive President of Hunan Normal University, Distinguished Expert of Government Special Allowance by State Council 2011, Vice Chairman of Teaching Steering Committee for Foreign Language and Literature Specialty in Colleges by the Ministry of Education 2018-2022, Chair of SubCommittee on Teaching Guidance for English Majors by the Ministry of Education 2018, Vice Chairman of National Steering Committee for Postgraduate Education of Translation by Academic Degrees Committee of State Council 2016. For further information see https://fsc.hunnu.edu.cn/info/1224/4532.htm

Submetido em 03/05/2020

Aprovado em 13/06/2020 